\title{
Effect of thyroxin induction on enzymatic and biochemical levels in albino rats
}

\author{
Jayashree V. Hanchinalmath ${ }^{1, *}$, Kirankumar Shivasharanappa ${ }^{1}$, \\ T. S. Roopa ${ }^{2}$, Y. Saisundeep ${ }^{3}$ \\ ${ }^{1}$ Department of Biotechnology, Gulbarga University, Gulbarga - 585106, Karnataka, India \\ *Tel. Ph: 8892120330 \\ ${ }^{2}$ Department of Botany, Karnataka University, Dharwad - 580003, Karnataka, India \\ ${ }^{3}$ Department of Botany, Sikkim Central University, Gangtok - 737102, Sikkim, India \\ *E-mail address: jayhanchinal@gmail.com
}

\begin{abstract}
The albino Wistar rats were used to investigate the effect of thyroxine administration on the activity of citric acid, $\alpha$-Amylase, creatine phosphokinase (CPK), creatinine, cholesterol and triglycerides level in blood serum and citric acid in liver and kidney. Two groups of rats were taken for the experiment. One group was injected subcutaneously with $200 \mu \mathrm{l}$ of thyroxine $/ 50 \mathrm{~g}$ of body weight, the other group served as control. The animals were vivisected with anesthesia after intervals of 24, 48, 72 and 96 hours $\alpha$-Amylase and CPK levels in blood; citric acid level in liver and kidney of control and thyroxine treated rats. The results showed that the $\alpha$-Amylase activity remained unaltered $(100 \mathrm{~g} / \mathrm{h} / \mathrm{l})$ throughout the experiment. However, citric acid level found to be $460 \mathrm{mg}$ in the liver and $415 \mathrm{mg}$ in kidney of control rats. The values slightly increased to 480 and $680 \mathrm{mg}$ in respective tissues of thyroxine treated animals for $24 \mathrm{hr}$. The values decreased in 48 and 72 hours of treatment. Further the values found to be increased after 96 hours of treatment. Although the thyroxine treatment altered citric acid, Creatinine, Cholesterol, Triglycerides and CPK levels in the tissues, the serum $\alpha$-Amylase was not influenced by the thyroxine. The study suggests that the thyroxine acts as a regulator all the above parameters in the cellular level.
\end{abstract}

Keywords: Thyroxine; $\alpha$-Amylase; Kidney; CPK

\section{INTRODUCTION}

Thyroxine is secreted by the thyroid gland. The hormone thyroxine forms by combining the amino acid tyrosine with iodine. Complexed to a protein, it is stored in the follicle stems between thyroid cells. Thyroxine enters into the bloodstream complexed to another protein, plasma globulin ${ }^{1}$. Thyroxine increases the number and activity of mitochondria in cells by binding to the cell's DNA, increasing the basal metabolic rate. Administration of thyroid hormones, such as thyroxine, causes an increase in the rate of carbohydrate metabolism and a rise in the rate of protein synthesis ${ }^{2}$. Deficiency of thyroxine is associated with endothelial dysfunction, arterial hypertension, and impaired kidney function. It is also described that thyroxine alters serum creatinine, glomerular filtration rate and renal blood flow in rats. These 
consequences may result from several mechanisms, including direct and indirect effects of thyroid hormones on blood vessels. The changes in serum creatinine, was found after thyroxine replacement therapy in human, the value was above the reference interval at diagnosis of hypothyroidism in patients and decreased. Thyroxine may improve endothelial function and renal blood flow, in rats. The value of serum creatinine decrease in hypothyroid patients treated with thyroxine. Many studies have yielded evidence that the development of enzymes in liver is under multiple hormonal control ${ }^{3}$. Thyroxine has an important function in altering levels of creatine kinase ${ }^{4}$. Citric acid is a weak organic acid, and it is a natural preservative and is also used to add an acidic, or sour, taste to foods and soft drinks. In biochemistry, it is important as an intermediate in the citric acid cycle and therefore occurs in the metabolism of almost all living things. It also serves as an environmentally benign cleaning agent and acts as an antioxidant and a lubricant ${ }^{5}$. Effect of thyroxine on citric acid synthesis activity and it is an index of mitochondrial oxidative capacity in vertebrates ${ }^{6}$. Triglycerides are a form of fatty acid esters. They are produced in the liver by binding glycerol and other fatty acids. Increase levels are found in hyper lipidemias, diabetes, nephritic syndrome and hypothyroidism. Increased levels are risk factor for arteriosclerotic coronary disease and peripheral vascular disease. Decreased levels are found in mal nutrition and hyperthyroidism. Albino Wistar rat, is one of the best-known and common rats. Thought to have originated in northern China, this rodent has now spreaded to all continents (except Antarctica). It is the dominant rat in Europe and much of North America. Selective breeding of albino rats has made it an important model organism in biological research.

\section{MATERIALS AND METHODS}

The experimental animals of 28-30 days weighing about $80 \mathrm{~g}$ were used in the experiment. The animals were divided into two groups. One group was injected subcutaneously with $200 \mu \mathrm{l}$ of thyroxine whereas the other group served as control. The experimental animals were vivisected with anesthesia after intervals of 24, 48, 72 and 96 hours. $2 \mathrm{ml}$ of blood was drawn to estimate blood parameters.

\section{$\alpha$-Amylase}

The method is based on photometric determination of starch consumption during starch hydrolysis reaction (amyloclastic method) by $\alpha$-amylase of blood serum ${ }^{7}$. The difference of starch concentrations before and after hydrolysis is presumed to be proportional to the enzyme activity. To test tubes (sample and control), transfer $0.5 \mathrm{ml}$ of starch solution, $0.3 \mathrm{ml}$ of phosphate buffer, and $0.1 \mathrm{ml}$ of sodium chloride solution. Mix the contents shaking and place the test tubes in a water bath $37^{\circ} \mathrm{C}$ for 10 minutes. To the sample solution, add $0.1 \mathrm{ml}$ of blood serum. To the control solution, add $0.1 \mathrm{ml}$ of hydrochloric acid solution and $0.1 \mathrm{ml}$ of blood serum. Mix thoroughly the contents with shaking and place the test tubes in a thermostat set at $37{ }^{\circ} \mathrm{C}$, wait 30 minutes until the reaction is terminated. Add $0.1 \mathrm{ml}$ of hydrochloric acid solution to the sample test tube and mix the contents with vigorously to stop the reaction. Take $0.2 \mathrm{ml}$ of the mixture from both test tubes and transfer the samples to two graduated flask of $50 \mathrm{ml}$ capacity. Pour $40 \mathrm{ml}$ of distilled water into each flask and add $0.5 \mathrm{ml}$ of iodinated potassium iodine solution. Mix the content with swirling and then make up to the mark with distilled water. Measure immediately the absorbance for both solutions against distill water at 630-690 $\mathrm{nm}$ (red light filter) in photo colorimeter using $1 \mathrm{~cm}$ thick cells. 


$$
X=\frac{(\mathrm{E}-\text { control }-\mathrm{E}-\text { sample }) 0.01 \times 2 \times 1000}{\mathrm{E}-\text { control } \mathrm{x} 0.1}
$$

\section{Creatine phosphokinase (CPK)}

The method is based on the determination of creatine produced from creatine phosphate by the action of $\mathrm{CPK}^{8}$. The activity of this enzyme is estimated by the amount of creatine produced. Add successively to two test tube (sample and control) the following reagent listed in the below table.

\begin{tabular}{|c|c|c|}
\hline Reagent & Sample (ml) & Control (ml) \\
\hline Tris-buffer & 0.2 & 0.2 \\
\hline Distilled water & 0.2 & 0.3 \\
\hline Creatine phosphate & 0.1 & 0.1 \\
\hline Blood serum & 0.1 & - \\
\hline
\end{tabular}

Incubate the test tubes in water bath at $37^{\circ} \mathrm{C}$ for $3 \mathrm{~min}$; add $0.2 \mathrm{ml}$ of ADP solution to each test tube. After $30 \mathrm{~min}$, stop the reaction by adding $0.2 \mathrm{ml}$ of barium hydroxide and 0.2 $\mathrm{ml}$ of Zinc sulfate solution. Allow the content to cool for $10 \mathrm{~min}$. Centrifuge the solution and take the $0.5 \mathrm{ml}$ supernatant and add $3 \mathrm{ml}$ of distilled water, $1 \mathrm{ml}$ of alfa- naphthol solution and $0.5 \mathrm{ml}$ of diacetyl solution. Mix thoroughly, place the test tube in the dark chamber for 20 min for developing coloration. Standard control solution is prepared by using creatine solution. Read the optical density at $520-540 \mathrm{~nm}$ using green filter. The activity of CPK is calculated by using the formula:

$$
\mathrm{X}=0.00005 \mathrm{E}_{\text {sample }} \times 1.2 \times 2 \times 10000 / \mathrm{E}_{\mathrm{st}} \times 0.5
$$

whereas, $\mathrm{X}$ is the activity of $\mathrm{CPK} \mathrm{mmol} / \mathrm{h}^{-1} / \mathrm{l}^{-1}$

0.00005 is the concentration of Creatine in the standard solution mmol

$\mathrm{E}_{\text {sample }}$ is the absorbance measured for the sample solution against the control solution

$\mathrm{E}_{\mathrm{st}}$ is the absorbance measured for the standard control solution against the control solution

2 is the scaling factor

0.5 is the volume of supernatant liquid sampled for analyses

10000 is the scaling factor for conversion to /lt blood serum

\section{Serum creatinine}

Creatinine reacts with alkaline picrate to produce a reddish color, this is nonspecific reaction and is given by many other substances $1 \mathrm{ml}$ of blood serum was collected in the heparinised syringe and estimated by ${ }^{9}$.

\section{Total cholesterol}

Total cholesterol and triglycerides was estimated by the method of ${ }^{10}$. Transfer $2.1 \mathrm{ml}$ of Ilca's reagent to a test tube and add $0.1 \mathrm{ml}$ nohemolised blod serum in small proportion 
allowing them to flow down the innerwall of the test tube. Shake vigorously and place the test tubes in the thermostat set at $37^{\circ} \mathrm{C}$ for $20 \mathrm{~min}$. Take the optical density at $630-690 \mathrm{~nm}$ in red filter against the blank. Tryglycerides in the blood sample was estimated by using enzyme reagents. $1 \mathrm{ml}$ of working reagent mixed with $100 \mathrm{ul}$ of sample incubated at $37^{\circ} \mathrm{C}$. Measure the absorbance against blank at $546 \mathrm{~nm}$ with green filter.

\section{Citric acid}

The tissues like liver and kidney were collected to estimate Citric Acid by following the method of $^{11}$. Take $25 \mathrm{mg}$ of tissue and $2 \mathrm{ml}$ of sulfuric acid. Adjust to about $20 \mathrm{ml}$, boil for few min, cool and add 3-5 $\mathrm{ml}$ of bromine water. Precipitate formed was removed by centrifugation and supernatant was made up to $25 \mathrm{ml}$. Add $0.3 \mathrm{ml}$ of sulfuric acid, $0.2 \mathrm{ml} \mathrm{KBr}$ and $1 \mathrm{ml}$ of $1.5 \mathrm{~N}$ potassium permanganate. Make volume to $5 \mathrm{ml}$. Incubate at room temperature for $5 \mathrm{~min}$ and then chilled in an ice bath. The excess permanganate is decolorized with sulfuric acid and kept at $5{ }^{\circ} \mathrm{C}$. Weak permanganate was added to remove excess sulfuric acid. Make up the volume to $10 \mathrm{ml}$ and add $13 \mathrm{ml}$ of petroleum ether. Test tubes were stoppered, shaken vigorously and centrifuged. To $10 \mathrm{ml}$ supernatant, $5 \mathrm{ml}$ water dioxane and $5 \mathrm{ml}$ of sodium sulfide was added. Read optical density at $400-450 \mathrm{~nm}$.

\section{RESULTS}

In the present experiment the $200 \mu 1$ of thyroxine was injected intraperitonially to the rats. The estimations were carried out to evaluate the amount of Citric acid present in liver and kidney. The blood serum was drawn to estimate the amount of Creatine phosphokinase (CPK), Serum Creatinine (SC) Cholesterol, Triglycerides (Tgd) and $\alpha$-Amylase.

Fig. 1. Citric acid content in liver and kidney of control and thyroxine injected rats.

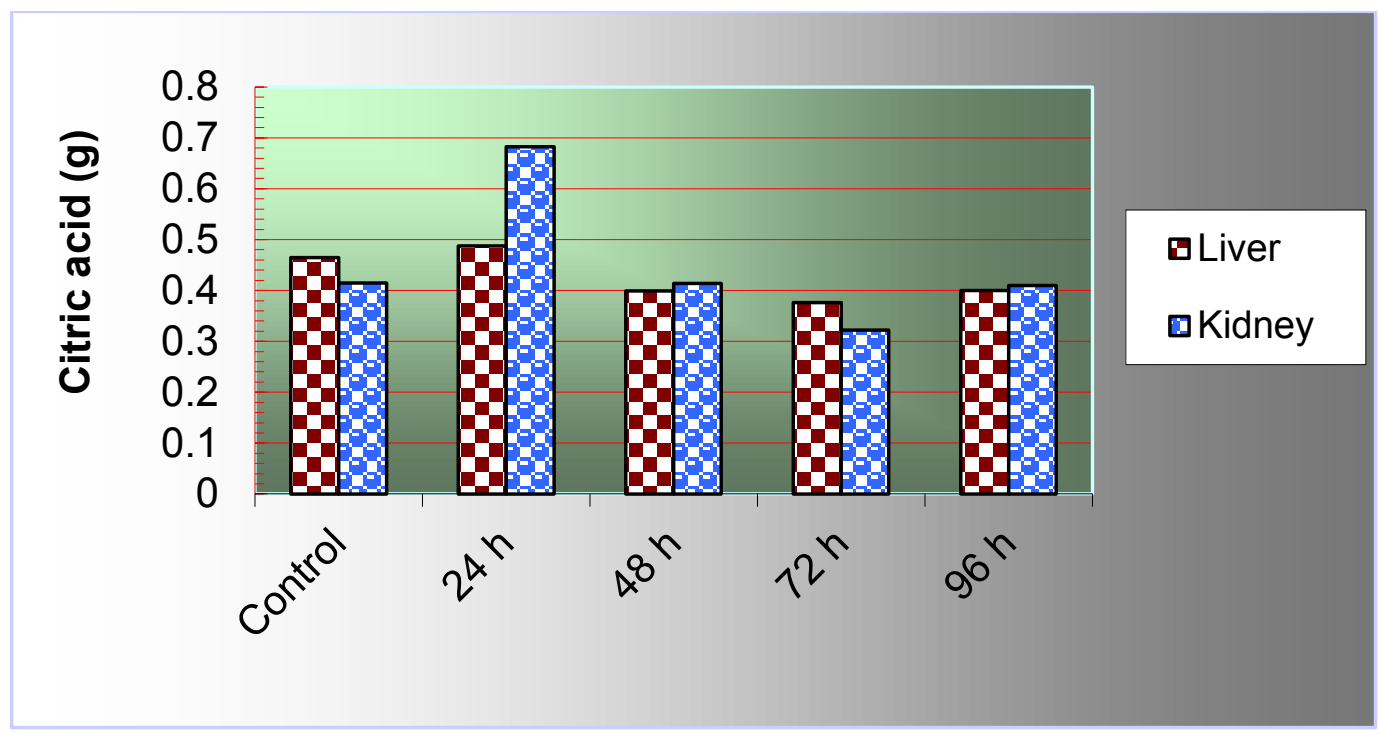

The citric acid level (Fig. 1) in the control liver of rat showed $0.465 \mathrm{~g}$. The value increased slightly in the animals injected with thyroxine for $24 \mathrm{~h}$. Further the values decreased to $0.399 \mathrm{~g}$ in $48 \mathrm{~h}$ and $0.376 \mathrm{~g}$ in $72 \mathrm{~h}$. However, the value further increased 
slightly to $0.40 \mathrm{~g}$ in $96 \mathrm{~h}$ of treatment. The citric acid level was found to be $0.415 \mathrm{~g}$ in the kidney of control rats. The value increased to $0.683 \mathrm{~g}$ in the animals injected with thyroxine for $24 \mathrm{~h}$. The values decreased rapidly to $0.414 \mathrm{~g}$ in $48 \mathrm{~h}$ and $0.322 \mathrm{~g}$ in $72 \mathrm{~h}$. However, the value further increased slightly to $0.41 \mathrm{~g}$ in $96 \mathrm{~h}$ of treatment.

The total Creatinine phosphokinase activity (Fig. 2) was found to be $25 \mathrm{U} / 1$ in the controlled rats. Further the activity increased in the rats treated for $24 \mathrm{~h}(40 \mathrm{U} / 1)$ and $48 \mathrm{~h}(49$ $\mathrm{U} / \mathrm{l})$. However the activity decreased to $37 \mathrm{U} / \mathrm{l}$ in $72 \mathrm{~h}$ and $30 \mathrm{U} / \mathrm{l}$ in $96 \mathrm{~h}$ of rat serum.

Fig. 2. Creatine phosphokinase (CPK) in tissue of control and thyroxin injected rats.

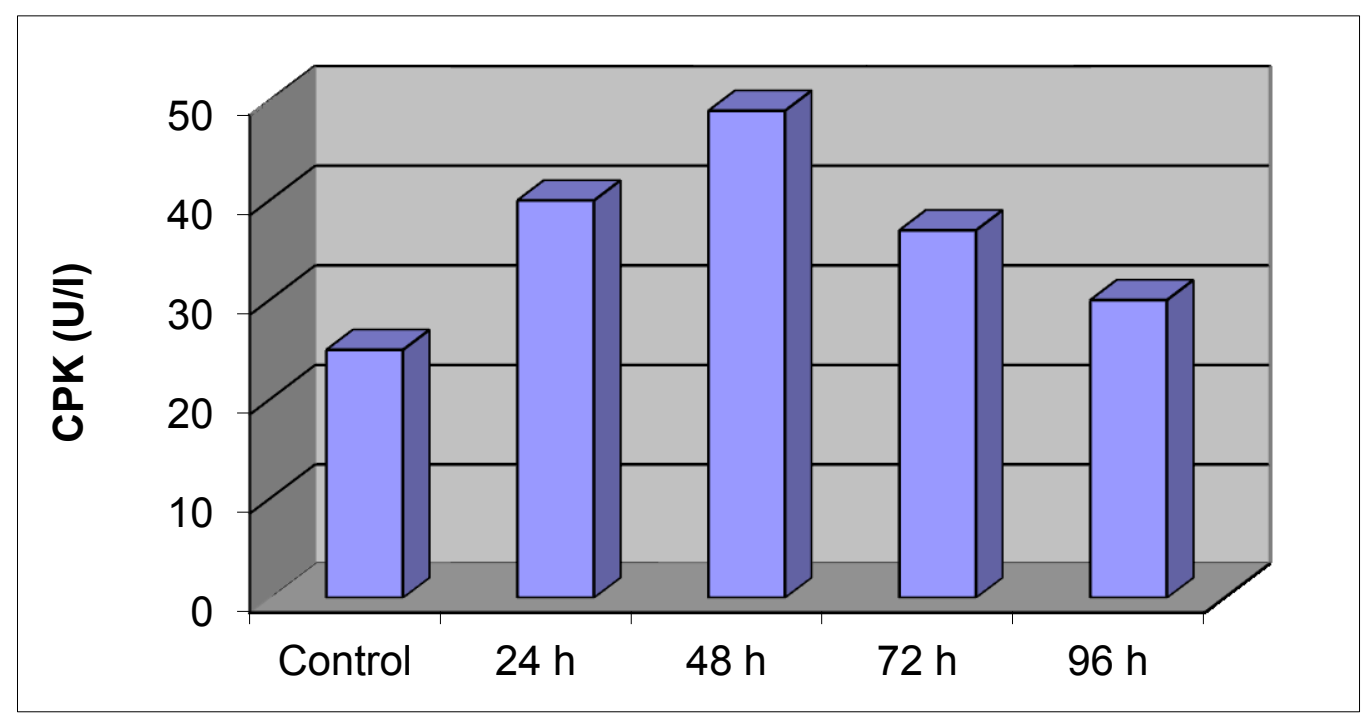

Fig 3. Serum Creatine in tissue of control and thyroxine injected rats.

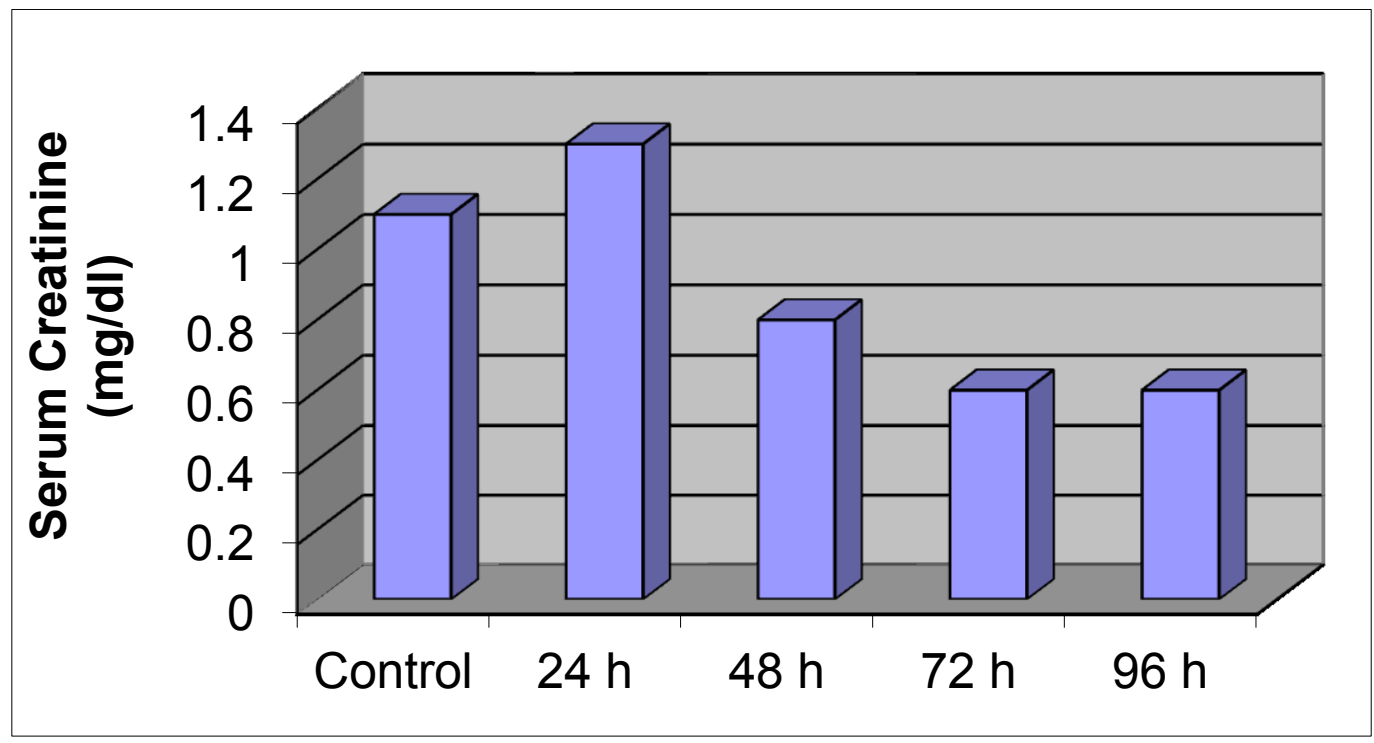

The Serum Creatinine level (Fig 3) in the control serum of rat showed $1.1 \mathrm{mg} / \mathrm{dl}$. The value increased slightly in the animals injected with thyroxine for $24 \mathrm{~h}$. further the values decreased to $0.8 \mathrm{mg} / \mathrm{dl}$ in $48 \mathrm{~h}$ and $0.6 \mathrm{mg} / \mathrm{dl}$ in $72 \mathrm{~h}$. and the value remain constant in $96 \mathrm{hr}$. 
Fig. 4. Cholesterol (mgs/dl) in tissue of control and thyroxine injected rats.

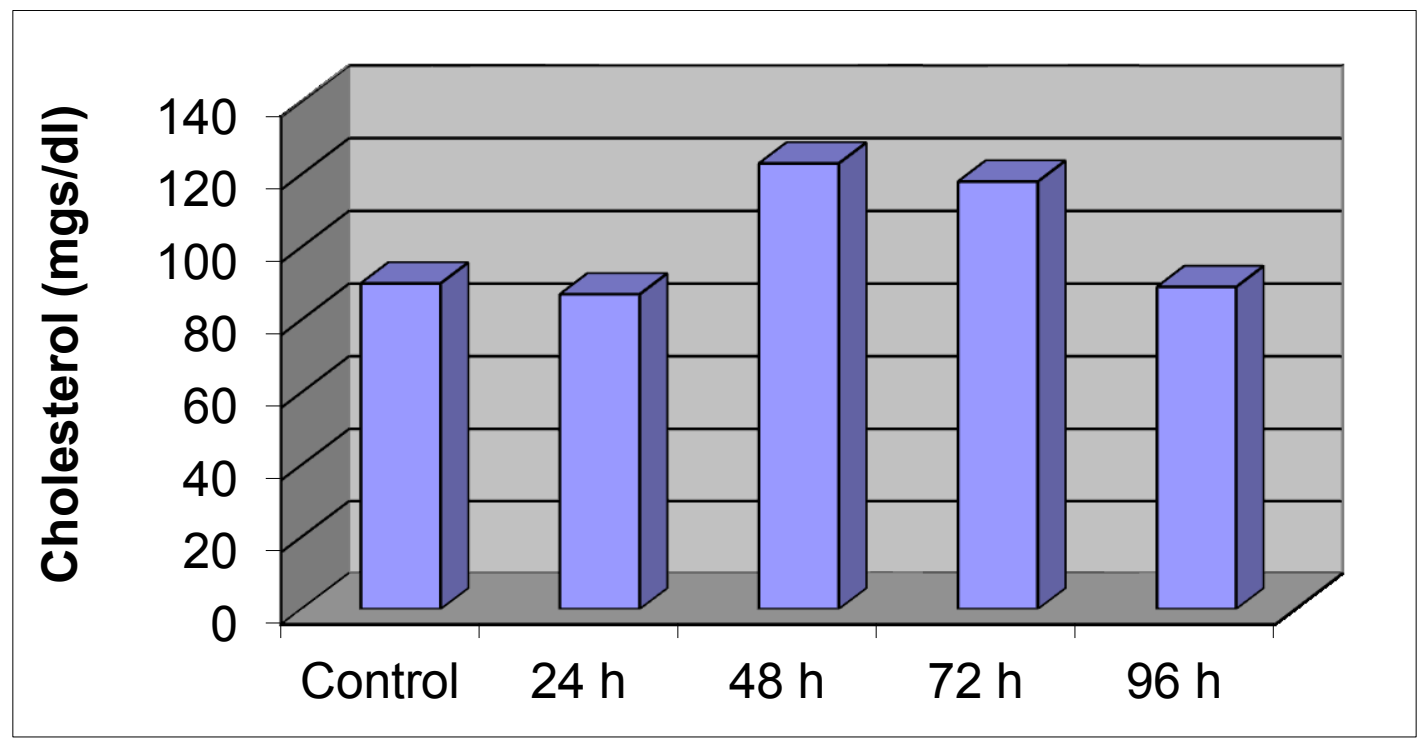

The Cholesterol level (Fig. 4) was found to be $90 \mathrm{mg} / \mathrm{dl}$ in the serum of control rats. The value decreased suddenly to $87 \mathrm{mg} / \mathrm{dl}$ in the animals injected with thyroxine for $24 \mathrm{~h}$. further the values increased rapidly to $123 \mathrm{mg} / \mathrm{dl}$ in $48 \mathrm{~h}$. However, the value further decreased slightly to $118 \mathrm{mg} / \mathrm{dl}$ and $89 \mathrm{mg} / \mathrm{dl}$ in 72 and $96 \mathrm{hr}$.

Fig. 5. Triglycerides (mgs/dl) in tissue of control and thyroxine injected rats.

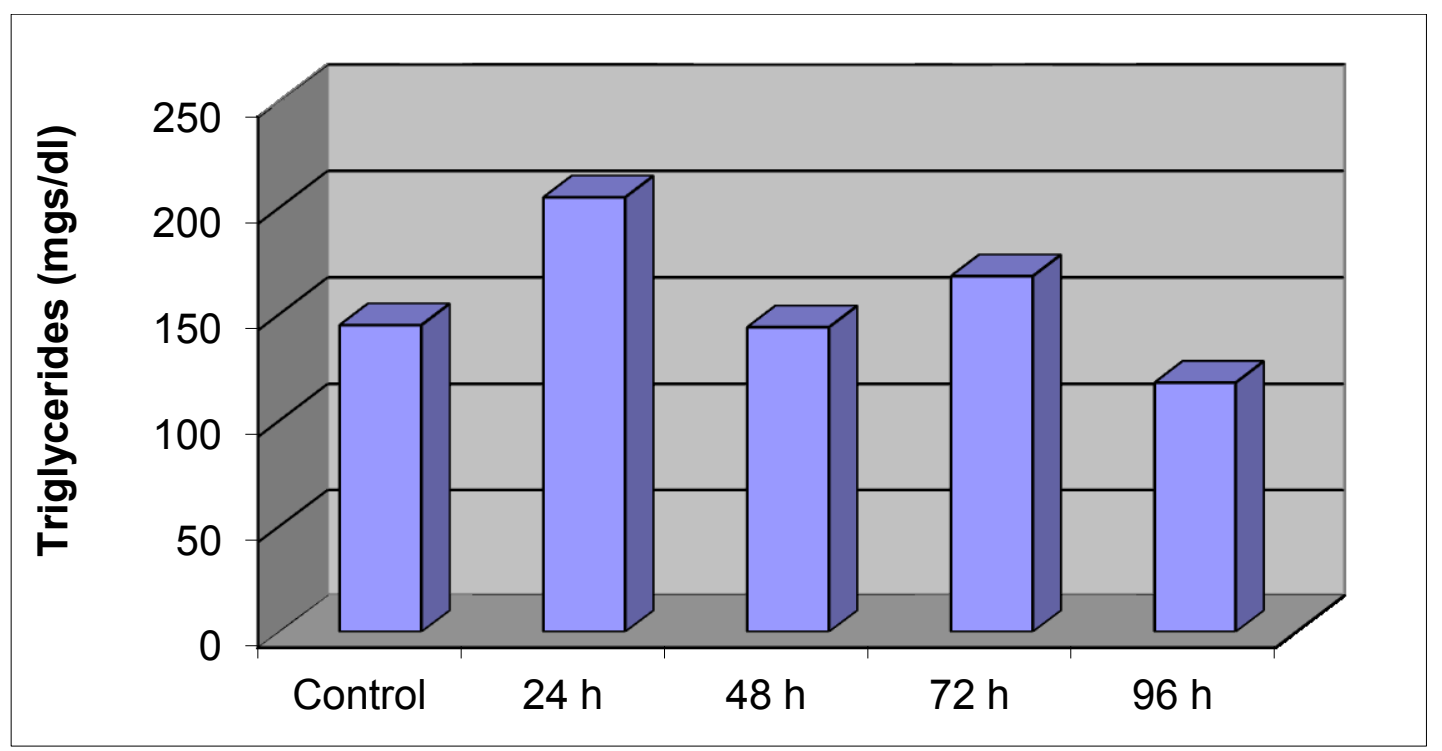

The Triglycerides level (Fig. 5) was found to be $145 \mathrm{mg} / \mathrm{dl}$ in the serum of control rats. The value increased suddenly to $205 \mathrm{mg} / \mathrm{dl}$ in the animals injected with thyroxine for $24 \mathrm{~h}$. further the values decreased rapidly to $144 \mathrm{mg} / \mathrm{dl}, 118 \mathrm{mg} / \mathrm{dl}$, in $48 \mathrm{hr}$ and $96 \mathrm{hr}$ respectively. 
The experimental results showed that the $\alpha$-Amylase content remain constant as $100 \mathrm{~g} / \mathrm{h} / \mathrm{l}$ throughout the experiment.

\section{DISCUSSION}

Thyroxine play important role in regulating the development of mammalian tissues. The mechanism by which it modulates the developmental process is not fully understood. The previous studies indicated that the injection protocol results in suppression of natural thyroid secretory activity and average plasma thyroxine level ${ }^{12}$. Hypothyroxine level in rat pups, induced the development of exocrine enzymes. Replacement of thyroxine alleviated the suppression of exocrine enzyme development in these rats. In the present investigation the thyroxin effect on the citrc acid level in the tissue of rats. The citric acid content of animal tissues with reference to its occurrence in bone and tumor was studied by ${ }^{13}$. The citric acid cycle is central to the regulation of energy homeostasis and cell metabolism ${ }^{14}$. The results in the present investigastion clearly indicated that the thyroxine influence on the citric acid activity in the tissues and also indicated the intermediates of the citric acid cycle are present at micromolar concentration in blood regulated by respiration, metabolism and renal reabsorption ${ }^{15}$.

Creatine phosphokinase (CPK) also known as Creatine kinase (CK), or phosphocreatine kinase, is an enzyme expressed by various tissue types. It catalyses the conversion of creatine and consumes adenosine triphosphate (ATP) to create phosphocreatine and adenosine diphosphate $(\mathrm{ADP})^{16}$. Elevation of $\mathrm{CK}$ is an indication of damage to muscle. It is therefore indicative of injury, rhabdomyolysis, myocardial infarction, muscular dystrophy, myositis, myocarditis, malignant hyperthermia and neuroleptic malignan syndrome. Lowered CK can be an indication of alcoholic liver disease and rheumatoid arthritis.

Creatinine is chiefly filtered out of the blood by the kidneys, though a small amount is actively secreted by the kidneys into the urine ${ }^{17,18}$. If the filtering of the kidney is deficient, blood levels rise. Therefore, creatinine levels in blood and urine may be used to calculate the creatinine clearance $(\mathrm{CrCl})$. The amount of creatinine the body produces each day depends on the person's muscle mass. Decreased creatinine levels might be decreased muscle mass or inadequate dietary protein. Muscle atrophy can also result in decreased serum creatinine level. The only important pathological condition that causes a significant increase in the serum creatinine level is damage to a large number of nephrons, impaired renal function, chronic nephritis and urinary tract obstruction caused by the inducing effect of thyroxine.

Cholesterol is a lipidic, waxy alcohol found in the cell membranes and transported in the blood plasma of all animals. It is an essential component of mammalian cell membranes where it is required to establish proper membrane permeability and fluidity. Although cholesterol is essential for life, high levels in circulation are associated with atherosclerosis. Decreased HDL cholesterol in subclinical hypothyroidism. The values in the present studies increased initially and finally the content decreased in the rats injected with thyroxine for prolonged period. The results in this study suggest an important role of thyroxine hormone in the regulation of serum cholesterol in rats which makes fluctuation in the content. The correlation between increase in thyroxine and decrease in serum cholesterol was noticed earlier $^{19}$.

Triglycerides are the chemical form in which most fat exists in food as well as in the body. They're also present in blood plasma and, in association with cholesterol, form the plasma lipids. Hormones regulate the release of triglycerides from fat tissue so they meet the 
body's needs for energy between meals. Triglycerides are formed from a single molecule of glycerol, combined with three fatty acids on each of the $\mathrm{OH}$ groups, and make up most of fats digested by humans.

The $\alpha$-amylases are calcium metalloenzymes, completely unable to function in the absence of calcium. Amylase is found in saliva and breaks starch down into maltose and dextrin. This form of amylase is also called ptyalin. It will break large, insoluble starch molecules into soluble starches producing successively smaller starches and ultimately maltose $^{20}$. Daily injection of thyroxine to rats starting at day 5 of age resulted in precocious increases of exocrine enzymes in the pancreas of the rats and thyroxine has both direct and indirect modulatory roles in the development of the rat exocrine pancreas. In the present invetigation the $\alpha$-Amylase activity remained constant in the experimental rats.

\section{CONCLUSION}

The findings of this investigation provided information on changes in physiological and biochemical systems in albino rats injected with thyroxine. Further these systems interfere with the nature of homeostatic compensating mechanisms during the treatment with thyroxine, wherein the physiological and biochemical systems deviated from its normal range of variations mostly suppressive, thus leading towards the adaptation and maintenance of body metabolism during the hyperthyroxine condition.

\section{References}

[1] Walker, Science 204 (1979) 427-429.

[2] Settimio G., Jacob R., Harold E., Biochemistry 24(14) (1985) 3771-3776.

[3] Shainberg G. Yagil, Yaffe D., Dev Biol 25(1) (1971) 1-29.

[4] Yaffe O. Saxel, Nature 270 (1992) 725-727.

[5] Penniston K. L., Nakada S. Y., Holmes R. P., Assimos D. G., Journal of Endourology 22(3) (2008) 567.

[6] Holloszy H. O., Winder W. W., Am. J. Physiol. 236(3) (1979) 180-183.

[7] Stroev E. A., Makarova V. G., In, Rassadin BV. Physicochemical studies of protein properties. Laboratory Manual in Biochemistry; Moscow: Mir Publishers; 1989; 45-47.

[8] Stroev E. A., Makarova V. G., In, Rassadin BV. Physicochemical studies of protein properties. Laboratory Manual in Biochemistry; Moscow: Mir Publishers; 1989; 45-47.

[9] Fabing D. L., Ertinghausen G., Clin Chem 17 (1971) 391.

[10] Trinder P., Annals of Clinical Biochemistry 6 (1969) 24-27.

[11] Natelson S., Lugovoy J. K., Pincus J. B., J. Biol. Chem 170 (1947) 597.

[12] Schibler M. Tosi, Pittet A. C., Fabiani L., Wellauer P. K., J Biochem 95(3) (1984) 697 702.

[13] Frank Dickens, Biochem J 35(8-9) (1941) 1011-1023.

[14] Krebs H. A., Perspect Biol. Med 14 (1970) 154-170. 
[15] Wittenberger T., Schaller H. C., Hellebrand S., J. Mol. Biol 307 (2001) 799-813.

[16] Mcleish M. J., Kenyon G. L., Crit. Rev. Biochem. Mol. Biol 40(1) (2005) 1-20.

[17] Schlattner U., Tokarska-schlattner M., Wallimann T., Biochim Biophys Acta 1762 (2) (2006) 164-180.

[18] Wallimann T., Wyss M., Brdiczka D., Nicolay K., Eppenberger H. M., Biochem J 281(1) (1992) 21-40.

[19] Elder, Ann-Clin-Biochem 27(2) (1990) 110-3.

[20] Fried M., Abramson S., Meyer J. H., Digestive Diseases and Sciences 32 (1987) 10971103. 